\title{
The Crisis of Big Politics
}

\author{
IVAN VALENTE
}

$\mathrm{T}$

HIS CRISIS, which questions politics itself, is not new. What is new is its transformation into a media spectacle; its visibility and the reasons for its evolution, which demand a more analytical view of the problem. Thus, it must be asked: what is the crisis of the Parliament? What is meant by crisis? What is at the foundation of this crisis, which is far from being a word that reveals the seriousness of the problem, and which has become commonplace, waiting for just one more fact to confirm the thesis of the unimportance of political activity or of its association with amoral and private values?

The first realization is that the unimportance of politics as the decision making sphere of public destinies - which is confused as being only the occasional act of voting - is a current phenomenon. This "unimportance" is increasingly amplified by the enormous economic weight of the corporations, which make valueless the controls citizens have over public life. In the government sphere, the decisions of the Central Bank to set interest rates are much more important than most of the decisions of the Parliament. And the Central Bank, unlike the other branches of power of the Republic, is not directed by anyone elected by popular vote. As sociologist Francisco de Oliveira says, there is a broad trend towards "the colonization of the political by the economic."

The second finding is that the advance of globalization and the acceleration of the processes of capitalist accumulation make the symbiosis between State and private corporations much faster than the forms of regulation of politics. In the realm of Parliament and the production of laws, this symbiosis results in a government where everything is done in exception to the rule, in which the Executive governs based on decrees of provisional measures that always force the deputies to respond with urgency.

The third finding is that politics itself is increasingly reduced to a spectacle. In mass societies, with mechanisms for popular control and participation nearly nonexistent, the weight of the media is preponderant in the definition of that which is or is not important from the perspective of the public debate. Today, the media has the power to set the agenda of action for the National Congress. Thus, the form in which politics reaches the common citizen is mediated by a process that places the interpretation of the fact in front of the fact itself. That is, politics, to appear, is naturally framed in the scheme of small politics, or as a scandal that is easily approached through the focus on corruption. There is a preponderance, to use Grasmscian terminology, of small politics over large politics. 
Just analyze the example of the Parliamentary Investigative Commission of the Public Debt which, after we insisted considerably, was finally installed in the Congress. In recent decades, Brazil's public debt increased nearly ten times and has become a veritable garrote that imprisons and impedes the country in the international financial web, with all the consequences, including a lack of resources, sacrifice and poverty of most Brazilians. In 2008 alone, R \$282 billion were consumed in interest payments and debt amortizations, draining $47 \%$ of the budget of the Republic for debt services. This quantity of resources alone would be enough to demonstrate the degree of importance of this debate for the country. Nevertheless, the recent victory of the conservative sectors causes a blindness to this issue, making it prohibitive, keeping it out of the large communication media and little discussed in the National Congress.

These three factors - the colonization of politics by the economy, the ability of the Executive to act with greater urgency than the Parliament and the preponderance of small politics over big politics - reveal, therefore, the tendency towards subordination of politics by the economy. Politics is so unimportant that even the big issues appear to be decided outside of this sphere. Any attentive reader perceives that politics disappeared from the sections of the large newspapers dedicated to covering this issue. Politics today is revealed either in the economic sections, which portray the big deals that define the life of millions but which emerge little to the public sphere, or in the local sections, that deal with the true social crisis in which the country is plunged, characterized by the absence of resources for the social fields, the collapse and privatization of the healthcare system, the scrapping of public education and the explosion of violence in the poor perimeters of the large cities.

\section{When Small Politics is Functional}

To consider the crisis of the Legislative Branch from within a scope of an absence of ethics and a supposed morality has its functionalities. This is not a case of corroborating the affirmation of the authoritarian elites that the Brazilian people have no memory, but, in fact, treating the problems of the National Congress as consequences exclusively of the lack of political ethics serves the interest of those who want everything to stay as it is.

In one major corruption scandal to another involving large banks and corporations in ties of alleged conflicts of interest with politicians, or monthly payments to federal deputies, ultra-secret acts and the spectacularization of the manipulation of public resources, the message sent in unison to the Brazilian population is that our representative institutions are demoralized and delegitimized. The overdose of denunciations of corruption - which may not have increased, but only earn more new spotlights - create in the popular imagination the sense that this practice has become so commonplace and constant that it has contaminated all of politics. That is, corruption is something natural to the State and to Brazilian politicians, who, therefore, are not worthy or capable of 
participating in the democratic game and deciding the direction of the nation.

Better to leave this task to the Judiciary, the press and the private sector itself.

In this scenario, it is difficult to conceive of a Congress to define laws that truly regulate the market, break the monopoly of the large communication media, punish corruption in the private sectors and tax evasion, or establish mechanisms of control over the giant profits of the private banks..

It is clear that I do not intend to minimize the gravity of the cases of corruption that have come to light on the national scene. For decades, Brazilian democracy has lacked honesty and a strong moral position from its public agents. To struggle against corruption is one of the urgent tasks of our generation. If not confronted, we run the risk of passively witnessing the complete banalization of the role of the State. In this sense, it is necessary to recognize corruption as something historic, that is part of the continuity of the mechanisms of power in Brazil - power that has always been treated as the property of a conservative minority and which is focused on the maintenance of its privileges. This patrimonialist structure has never really been shaken.

We should, however, warn against the fact that it is always public administration that is the target of the charges, often for serious issues, that, as we have said, lack greater investigation and punishment of those responsible. The scandals that involve the action of the State in favor of the market and even the corruption of the private world do not receive the same publicity. What we can call the true large scandals, such as the refinancing to lose sight of the large debts of the federal government, states and municipalities; and the generous tax exemptions; the amnesty for tax evaders; the rescue of large companies that take adventures in the speculative market; the payment of the highest interest rates on the planet; and once again, the exorbitant spending of the federal government on the public debt, do not receive attention in the media.

This is not by chance. In this game of interests, which seeks to remove questions of big politics from the public debate, each movement is made with precision. In the current society of spectacle, the capitalist sectors of the Brazilian media are among the most influential in the definition of the political agenda that is to be addressed in the public debate - in and outside of Congress. Like a dog that runs after its own tail, the Brazilian parliament is today found in a vicious circle initiated by the charges of corruption that sprout from its corridors and offices and are fed daily by the repercussions in the press of these very charges.

One need only accompany the countless debates in the federal Senate about what public opinion thinks about the crisis that this body is facing. Instead of placing in practice measures to hold the guilty responsible and change the modus operandi of the Senate, our State representatives spend hours discussing what the press said to one another. Score a point for the Party of the Media, which in this way, achieves its incessant search for the depoliticalization of national politics and the deepening of what it defines as the crisis of the Legislature. 
When it does not turn its spotlights on cases of corruption, the media follows the neoliberal textbook and preaches the inefficiency and incapacity of the State, particularly concerning its role as promoter of rights and regulator of the market. Thus, the media attacks spending on public employees, defends privitizations and the reduction of the government machinery, exalts the current economic policy, calls for reduction of taxes and is silent on the CPI of the Public Debt. In this context of a fragile State, how is it possible to defend that the Legislative Power is, in fact, a branch of power with the ability to define the rules and laws for the functioning of the country? This opens the route to strengthening the sacred market - where it appears there is no corruption, poor management and scandals of various types - and for the seizure of the public by the private.

\section{Crisis of Representation}

The imposition of the economy over politics, of individual interests to collective causes, of the will of the market to the public interest, elements so particular to this neoliberal epoch, lead to a greater distancing of the population from political action and to a crisis of representation of the parliaments. This occurs throughout the world today. These representations are no longer capable of being carriers of identities, of national projects. The fragmentation and especially the professionalization of politics take on greater importance. There is no longer involvement in collective demands of a universal perspective, but corporativist, atomized struggles, whose horizon is the pressure on the Legislature concerning particular and immediate issues, leaving aside strategic issues.

In Brazil, the absence of the mechanisms of direct participation combined with those of indirect democracy and the form that our institutions have historically been constituted - with the people separated from political participation, in a colonial inheritance that has perpetuated in the Republic have facilitated the abyss between our Legislature and the population. There is little expectation, and obviously little confidence, in institutions that were always, with rare exception in history, distant and even inaccessible to the majority of the Brazilian people.

The 1980s held a promise of greater participation of the popular masses in our institutions, of their ascendance to positions of power and political action. These hopes arose soon after the end of the military dictatorship, with the previously repressed energy of a young and blossoming working class, which was the vanguard of an entire social struggle for which democracy was a central focus. Many contrast this with the fact that the changes were not completed in time and in the form in which the progressive sectors desired. A negotiated solution was reached that delayed direct elections and imposed a government that once again was elected indirectly.

Meanwhile, the organization of those below, the participation of millions of people in some form of effective associative democracy, in unions, community 
associations, housing construction collectives, that is, forms that guarantee not only participation, but especially learning, began to be built. Decisions in general, although there were obviously existing leaders, were taken in a broader manner and with some mechanism of popular consultation.

It was not by chance that the process of drafting the Constitution, despite the common attacks and manipulations of the powerful media and capital, was able to achieve more significant participation of the population. The debate about strategic questions reached the broadest elements of the masses, even if, as now, there were no practical and agile means to take this debate to the decision making forums. In fact, the effective result did not contradict the strategic interests of the dominant sectors, but some conquests were inscribed into the new Constitution that today would be unimaginable, such is the extent of the political retrocession that we have experienced.

This effective political participation was bombarded, fought without truce by the dominant sectors. After all, few things cause such antipathy from those who hold power than popular organization. The entities and forms of participation were systematically discredited, and the mechanisms for participation, blocked once again, no longer exactly by force, but by the neoliberal hegemony. This led to the depletion of the social struggles, which obviously did not fail to exist, but became more scattered. The hegemony of capital grew. In this period of ascendance of neoliberalism, we experienced fundamental qualitative changes in the productive bases of society, directly implying a weakening of the forms of traditional organization and representation of the working class.

What we have seen since then has been overwhelming, and is largely reflected in the crisis of parliamentary representation that we experience today. It was a movement capable of irreversibly carrying sectors that had once fought the liberal model of democracy, leading them to accept the rules of the game, as the only ones possible. This was the only route possible to construct democracy. This established a process of cooptation, by the dominant ideology, of the political and cultural leaders of the subaltern classes, to exclude them from an effective protagonistic role in the process of social transformation, as Carlos Nelson Coutinho indicated.

And when, by the surrender of much of the left, the class struggle is forced to pass far from the Parliament and loses sight of the clash of ideas, the pedagogical role of the conflict and of the ideological dispute, the public interest and the cause of those below is excluded from the game. "In the parliament, the ideological struggle is condemned and political confrontation rejected, as recommended by the 'theoreticians' of so-called post-modernity," affirms Caio Navarro de Toledo (2001).

The Lula government is the greatest expression of this process. It is not by chance that, to maintain governability at any cost, it uses mechanisms of corruption, opportunist Alliances and shady deals. It unites with retrograde 
sectors of Brazilian politics and denies its history and the origin of its formation. It enters the field of pragmatism, making choices without principal, from the range of possible choices. It does not dare to transform anything, it simply reinforces the mechanisms that always separated the organized population from political decisions. His government is the greatest expression of how politics became small.

When the strategic option of the left under the hegemony of the Workers Party (PT) came to be the conquest of government and not the State - by electoral means, with the lowering of its program and demobilization of the social force for change - the choice was made to enter the game of conciliation of classes and possible accords. The interest of the popular classes remained outside the question because there was only room for previously defined outcomes. This opened the door for generalized corruption. A containing wall was broken down and even worse, an idea began to dominate that benefited those above - the "depoliticization" of politics - one which says that all the parties are equal. This is a severe setback. For large capital, there could not have been a better situation: the greater the distance of the people from politics, participation and Parliament, the better for the perpetuation of its strategic interests.

\section{For an Effective Political Reform}

Although extremely troubling, this situation cannot be confused with a type of historical freeze. That is, one cannot understand that the dominant classes have already won and there is no possibility for change. In a country with social inequalities like those of Brazil, political instability is inscribed on the horizon, even if today sectors that once struggled wind up playing a strategic role for the maintenance of order. To combat the distancing of the people from politics, it is necessary to develop more advanced forms of popular participation, organization and control over the Parliament.

We know who is served by the State and the institutionalism that organizes the dominant relations in our country. This institutionalism is far from neutral. Despite presenting itself as if it was above everyone, it lacks a content aimed at serving the domination and interests of the large property owners, of capital, and more specifically, the current predominance of financial capital. That is, there is a concrete class content.

In this analysis, one cannot lose sight of the majority sectors in the composition of Parliament: the regional oligarchies, the representatives of financial capital, of agribusiness, of the large media and their connections that are reflected in the decisions made. Nor can we forget how the parliamentarians are elected, through private financing with large sums, which places a chain around the neck of each politician and pre-determines the interests that will be defended.

Finally, the seductive relationship between the Executive and Legislative powers must be considered. Today we have a super-strengthened Executive that legislates by means of Provisional Measures and has the capacity to co-opt 
parliamentarians by means of funds, the distribution of budget amendments and government jobs, making commonplace the pilgrimage of parliamentarians through the ministries, turning politics into a business deal. This is combined with the weakening of the political parties and the preponderance of pragmatism in political decisions, with the loss of well defined ideological references. The adhesion to the government, for example, is made more for survival than because of affinity - this gives rise to opportunistic and clientelistic relations, which involve all kinds of spurious exchanges and relations.

For all these reasons, effective political reform becomes important, one that can combat the elitist manner that politics is conducted in the country and guarantee popular participation and effective mechanisms of transparency and public control. The recent changes in the electoral rules, erroneously called reforms, in reality were nothing more than superficial adjustments, and did not combat central issues such as the end of private financing and even a ceiling to limit exorbitant spending on electoral campaigns. Thus, the disputes will become increasingly unequal.

To have more equal conditions for elections, it is necessary to approve exclusive public financing for campaigns, with rigid inspection and severe punishment for private financing, and transparency of spending by means of daily display on the Internet. Another mechanism that could fight the personalized distortions and at least create a possibility for a greater approximation with electoral disputes based on programs, proposals and ideas is the adoption of party lists with mechanisms that assure the rights of members of each party. In the same way, we include the possibility for revoking mandates and party fidelity, preserving the possibility of disagreement for ideological reasons. Finally, we defend mechanisms for transparency (like the end of the secret vote in Congress) of participation (like preference on the Congressional agenda for projects that are popular initiatives) and the use of tools for broad popular consultation (such as referendums and plebiscites).

The big question to be revived and which the movements for transformation have debated in recent decades, is not to deny them, but to advance in the democratic conquests that allow incorporation of the broad masses in political life. That is, to permit a political deepening of democracy with the growing socialization of politics. It is evident that this strategic demand has been more distant recently due to the relation of forces unfavorable to those below. But this does not remove its historic need. The crisis of representation of the institutions proves and raises with greater force the current nature the struggle for direct forms of public participation and control and inspection of the State.

For those who have not lost a transformative perspective, note the examples of the struggles that are being waged in Latin America. Without illusions, with their advances and setbacks, and many contradictions, so special to the moment that we live, they point to a strategic direction: that of popular protagonism and of new institutional arrangements that give space to 
this protagonism. It is not by chance, the first measures of the transformative governments in Venezuela, Bolivia and Ecuador were to use the tool of a National Constitutional Assembly and adapt their constitutions to popular participation. Contrary to what the large media raves about so much, democracy and the experience of popular participation are the great touchstones of the changes experienced by these countries, in direction of the construction of a new social order.

\section{Bibliographic Reference}

TOLEDO, C. N. de. Cenas parlamentares: simbolismos de submissão ideológica. Article published on the site Gramsci e o Brasil. 2001. At: <http://www.acessa.com/gramsci/?p age $=$ visualizar\&id=248>. Accessed on: Oct. 6, 2009.

Ivan Valente is federal deputy for The Socialism and Liberty Party (PSOL) of São Paulo.@-ivalente@uol.com.br

Received on 9.21.2009 and accepted on 9.25.2009.

Translated by Jeffrey Hoff. The original in Portuguese is available at http://www.scielo. br/scielo.php?script=sci_issuetoc\&pid=0103-401420090002\&lng=pt\&nrm=iso. 